\title{
Not Another Grim(m) Tale: The Rights of Passage in Marie von Olfers' "Little Princess"
}

\section{By Bernadette H. Hyner}

๑)

f we accept, as Edward Said suggests, that the terms authorship and authority both emphasize a writer's capacity to establish an alternative discourse, control, and preserve it, then Marie von Olfers is best remembered as a tale spinner who redrafts conventional gender designations in her fairy tales. ${ }^{1}$ Specifically, her narrative "Little Princess," published in 1862, presents alternative interpretations of female agency and sisterhood, while it also debases traditional concepts of family. Von Olfers' unusual reading of these topics suggests that she construes family and rites of passage in response, perhaps even in opposition, to her male predecessors' more traditional approach to the same themes.

My analysis of Von Olfer's depiction of family, sisterhood, and agency is informed by Shawn Jarvis', Karen Rowe's, and Jeannine Blackwell's research on fantasy narratives. ${ }^{2}$ These scholars concur that fairy tales originated primarily as parts of a female oral tradition, which, after the Grimm brothers, Hans Christian Andersen, and even Johann Wolfgang von Goethe appropriated it, was then reclaimed in women's literary 


\section{Sophie Journal}

circles such as the Kaffeter.

An additional cornerstone for my understanding of von Olfers' subversive tale is Jack Zipes' research on the metamorphosis of fairy tales as "an enrichment process" that gives birth to something new and unique in its own right." Zipes welcomes counter narratives as "progressive" since they frequently challenge the canonical narrative's "sexist and conservative $[\ldots]$ approach to $[\ldots]$ gender, justice, and government."4 The modus operandi in Speaking Out, Zipes' urban story-telling project, aims to alert youngsters to the manner in which canonical tales "reveal] the triumph of the oppressed" while their conclusions often "involve[ a restoration of the status quo with power largely in the hands of men" (115). My study builds on the critical observations made by Jarvis, Rowe, Blackwell, and Zipes in an attempt to delineate von Olfers' literary recasting of the conventional quest for autonomy.

Marie von Olfers (1826-1924), the daughter of Berlin's Museum director Ignaz von Olfers, and his wife Hedwig Stägemann, herself the child of a poet, was a co-founder of the Kaffeterkreis (1843-1848), a mid-nineteenth-century alliance of adolescent fairy tale writers and daughters of the Germanspeaking polite society. ${ }^{5}$ Their circle arose in response to male literary associations such as Berlin's famous Gelber Salon, in which Marie's father entertained the intelligentsia of the city. Although in 1846 the Kaffeter admitted the Grimm brothers and Hans Christian Andersen as honorary members, the circle remained primarily an association for women. The narratives that the Kaffeter members comprised re-imagine in terms of gender models the conventional fairy tale world. ${ }^{6}$

Early on, Marie von Olfers already demonstrated 
particular talents for drafting and illustrating tales, for which the Kaffeterkereis became a well-suited outlet. Initially, she used such narratives as mere catalysts for inspiration and salon conversation, while later her tale "Little Princess" and other narratives also enjoyed great popularity for their charming illustrations. ${ }^{7}$ Unfortunately, her skillfully comprised fairy tales are all but forgotten. ${ }^{8}$

Hence, few readers today are familiar with the tale of the "Little Princess," which traces adolescent (self-) discoveries and quests for autonomy (wish fulfillments) prior to culminating in the collaboration of two women characters. The narrative simultaneously depicts the coming-of-age stories of a penniless girl and that of a prosperous water sprite. Both characters must explore spaces outside of their homes. Mesmerized by the shimmer and sparkle of life under the sea, a curious adolescent, nicknamed "little princess," trades her nurturing home for the underwater riches of a friendly, equally adventurous sprite. As the human child takes possession of her new residence, she learns that life under water, as glorious as it may seem, lacks the tenderness of her all too distant mother. The nix, in turn, gains 'a soul' by learning to reciprocate the love she receives from her human foster family. At last, the narrative concludes with the mutual agreement of both heroines to live as sisters and share the embrace of the girl's impoverished mother.

As if to emphasize the merits of following one's inclination, the tale initially entices readers to take sides while it depicts two seemingly different protagonists. One heroine, adored by her mother and guarded by a "horde of rowdy brothers," grows tired of her family's decrepit financial disputation. She embodies the ambition to break free from 


\section{Sophie Journal}

home (217). ${ }^{9}$ The other protagonist, the sprite, seeks nothing more than a parent's loving embrace.

As von Olfers juxtaposes the hopes of leaving home and those of seeking it, the ostensibly simplistic plot conceals a rather significant complication in terms of its interpretation of the family. "Little Princess" adheres to and simultaneously breaks with conventional fairy tales, in that, much like a number of Grimm tales ("Cinderella" or "Snow White"), the narrative unfolds in a single parent home; yet this is not a conventional fairy tale plot in which the mother figure is erased. ${ }^{10}$ Instead, in von Olfers's tale the patriarch is absent. Given the absence of the father figure, a number of Grimm tales prescribe the restoration (i.e. remarriage) of the conventional family structure with a male figure at its center. ${ }^{11}$ Yet, in von Olfers' story, the absent patriarch has no consequence on the plot nor does the author give reasons for the absence. As an alternative, readers learn that this single parent home is a true haven and far from imperfect, even in the mind of the restless heroine, who eventually gives in to her $W$ anderlust. According to the little princess, it would simply take a few material things, fancy clothes, servants, a palace, but not a traditional father figure, to make her home 'ideal.' While the narrative steers clear of anchoring the family structure with a male breadwinner, it inadvertently validates an equally functional, less conventional family model with a loving but penniless matriarch at its center.

The presence of a caring parent, paired with one's belief that a character's sole pursuit of material goods rarely ends in her/his autonomy, may lead the reader to conclude that the little princess' quest for riches is imprudent and perhaps motivated by her naïveté. Yet, unlike a number of Grimmian tales that 
reprimand high-strung heroines - one need only to think of the haughty bride in "King Thrushbeard" or the conceited daughter in "The Frog King" - von Olfers' tale does not denounce the resolve of the heroine to determine her destiny. ${ }^{12}$ The little princess, as well as the heroines in "King Thrushbeard" and "The Frog King," seek forms of autonomy, but they do so for different reasons. Given that the above-mentioned Grimmian leads eventually must take husbands, the life of von Olfers' heroine stands out because marriage and motherhood do not hamper her ambitions. Instead of reinforcing the Germanic literary convention of the nineteenth century to silence and/or domesticate goal-driven women protagonists, the narrator of "Little Princess" sympathizes with the aspiration of the adolescent heroine and, therewith, validates her quest for a better life.

Next to endorsing an unconventional family structure and directing attention to the women in her tale, the narrator renders a less sympathetic description of the only male characters, namely the heroine's siblings. Indeed, she suggests that the peasant girl's "stately" (217), "stolz" (26) disposition and explorer spirit ("Now I am a princess" 217, "Jetzt bin ich eine Prinzeß" 28) predestines her for a splendid life, whereas her simpleton brothers lack imagination and drive. ${ }^{13}$ They aspire to nothing more than to remain "coarse peasant boys" (218), uninspired to enhance their lot (i.e. to "become princes" 218). ${ }^{14}$ While her siblings content themselves with playing in mud puddles, their sister ventures to the water's edge, taken with the rushing, sparkling water. At first glance, von Olfers' linking of her young explorer with the watery domain seems to contradict the author's break with conventional gender types, given that 


\section{Sophie Journal}

throughout literary history, prominent authors imbued water and its creature with notions of passivity and sentiment while linking it with the concept of the eternal feminine ("das ewig-weibliche Element"). ${ }^{15}$

Among the representations of the watery element, specifically the mermaid signals treachery, envy, deceit, or demise; Goethe's poem "The Fisher" ("Der Fischer" 1775), his fairy tale titled The New Melusine (Die Neue Melusine 1816), Andersen's "The Little Mermaid" ("Den Lille Havefrue" 1835), and the Grimmian tales "The Little Water Nixie" ("Die Wassernixe: 1812) and "The Nixie in the Pond" ("Die Nixe im Teich" 1843) make up but a few of many literary examples. ${ }^{16}$ "The Fisher" and the Grimmian tales depict the mermaid as a reclusive, even deadly temptress. It is perhaps for the imagined fatal quality of the water creature that Goethe drastically restricts her power in his New Melusine, in that he reduces the mermaid to a dwarf. Contrary to the misogynist suitor in his tale, who prefers keeping (i.e. domesticating) his demanding mermaid in a box, von Olfers undoes such restraint of the feminine. If we accept, as Laura Sells suggests, that conventional depictions of land and water as incompatible spaces create a hierarchical relationship which privileges as real the world of men (land), and inscribes its oblivion (and perhaps fear) onto the 'opposite,' muted (feminine) world of water, then von Olfers' narrative breaks this mold. ${ }^{17}$ Indeed, the author depicts the sprite (with her human counterpart) crossing repeatedly and willfully the supposedly impermeable boundary of the shoreline, and in the process, she deflates the hierarchies which the mermaid tales of the Grimms, Goethe, and Andersen uphold.

Next to enjoying her freedom of movement, the sprite 
also subverts Hans Christian Andersen's model of the mermaid whose immediate fascination with the human world is externally driven by her love for a land dweller. Andersen's water creature gains access to the prince only after she trades her voice and mobility for a human body. ${ }^{18}$ Von Olfers' sprite, instead, is internally driven by her wish for a more fulfilling life. Although this mermaid, like Andersen's water creature, wants to be loved, she first focuses her attention on her immediate surroundings. In an exchange with the mermaid's family, she emphasizes her dissatisfaction with her kin's lack of affection ("Can't you love me, hug me, like the humans do to each other?"' 219). ${ }^{19}$ Unlike Andersen's "Little Mermaid," whose siblings embrace her, the reaction of the mer-family to the sprite's request for a hug stresses the degree to which von Olfers' mermaid is already an outcast in her own home ("Do you understand what she wants? I don't, and if you don't either, it's probably just nonsense.' With that they [her relatives] flitted on past" 219). ${ }^{20}$ Specifically, in this scene von Olfers depicts two distinct generations of mermaids. The author regurgitates convention in depicting merfolk as soul-less (therefore love-less) 'cold fish' void of compassion, while she counterbalances this image with an alternative one. The adventurous sprite embodies a new generation of discontented water creatures who, because they strive for more fulfilling lives, eventually must cross the shoreline and gain souls.

The sprite shares this discontent with her human complement, the little princess, who rejects her simpleton brothers and the poverty that surrounds them. Given the sprite's ambition to better her life by relocating, we soon recognize that this character is not an opposite, but rather the 


\section{Sophie Journal}

little princess' double, her mirror image. ${ }^{21}$ They appear to have more commonalities than opposites. Much like her human counterpart, the sprite quests for change ("the nix didn't like it anymore below" 219) and must break with her family, albeit one that lacks the loving care of both father and mother. ${ }^{22}$ Indeed, the bewilderment of the human mother over her daughter's fascination with play at the water's edge mirrors the confusion of the mer-family over the sprite's wish for affection. As a consequence of her relatives' frigidity, the sprite too is "transfixed" on images of the world beyond the shoreline, however different these images may be from those of her human counterpart (219). ${ }^{23}$ If we then compare von Olfers' tale with Andersen's "Little Mermaid," we find that the reward of the heroines in "Little Princess" is power over their own lives, while Andersen's protagonist trades her voice, family, and mobility to gain security in adherence to power (i.e. the prince). ${ }^{24}$ The vocal and self-driven nature of the heroines in "Little Princess" therefore exceeds Andersen's more traditional depiction of acceptable behavior for women.

At the same time as von Olfers endorses the rights of women to enhance their lot, she highlights the kinship between her exploring protagonists ("now she [the princess] was splashing around [...], just like a little water sprite" 217$).{ }^{25}$ Given the tale's validation of female curiosity, the author elevates the adventurous girl over her simpleton brothers in the same manner as she promotes the sparkling water (and by extension the sprite that inhabits it) over the decrepit old mill where the little princess resides: "The water and the child - they looked like enchanted princesses in the midst of all the ugliness" $(217){ }^{26}$ 
Throughout literary history, water and the creatures associated with it have served as metaphors for the cycle of life and its unconscious manifestations. ${ }^{27}$ When the author links the little princess with the watery element, she not only echoes the girl's emerging $W$ anderlust in the ever rushing creek, but inversely also alludes to the hazards that await women who act on the wish to advance their lot. Indeed, the thrashing that the heroine earns for playing at the water's edge signals the mother's fear of losing her only daughter, while the subsequent lecture aims to curb the youngster's adventurous spirit.

“'Little Princess!' she [the mother] cried. 'You could have drowned! The water nix might have taken you to her palace. You silly thing, just imagine, taken away from your mother to her palace" $(218){ }^{28}$

Nevertheless, the risk of abduction by a creature, part human, part amphibian, fails to subdue the girl's enchantment with the underwater world. In an effort to sanction (rather than curb) female exploration, von Olfers displaces the principal concern of the mother. As if to unravel suggestions made in Goethe's poem ("The Fisher") and Andersen's tale ("The Little Mermaid") that link the mermaid's wish to 'cross over' (the shoreline) with loss and despair, von Olfers reveals the actions taken by her water creature to be life affirming. This mermaid 'crosses over' and (with permission of the little princess) gains access to a loving family, while with the sprite's cooperation, the human child enters and later returns from the watery kingdom without paying the ultimate price (i.e. death). Indeed, "Little Princess" dismantles the dualistic, hierarchical construction of the two spheres endorsed in a number of canonical tales that depict the world on land and that under water as two 


\section{Sophie Journal}

contrasting, incompatible spheres. The one on land is elevated as factual and real, as the other located below the surface is dismissed as fictive, imaginary, and muted. To be sure, von Olfers' heroines become privileged to access both, and in their quest to better their lot they learn to collaborate, a skill which facilitates their transition to adulthood.

Although the little princess conquers the perils of the underwater kingdom, a bigger challenge still awaits her. While she succeeds in leaving poverty behind, her departure nonetheless severs the connection to her mother. In fact, she gets so caught up in frivolous images of a carefree, beautiful life that she begins to resent her penniless mother, who cannot live up to the girl's dream of splendor (218). ${ }^{29}$ Taken with enchanting visions of grandeur, the princess "even $\mathrm{f}[\mathrm{in}] \mathrm{d}[\mathrm{s}]$ her mother ugly, [...] her gray hair matted and tangled, her nose like a fat red potato [...] wrinkled like an old witch's" (218). ${ }^{30}$ The heroine's demonic vision of the matriarch as a hideous monster brings to mind revolting, gynophobic images of autonomous women such as Ursula, the only other strong female character in the Disney adaptation of Andersen's tale, who must be slaughtered to complete the mermaid's 'crossing over. ${ }^{, 31}$ This type of imagery commonly serves to sanitize the cost of a girl's growing up, while it tends to make the separation from the mother/female elder more palatable. For this reason, young readers of the Grimmian "Cinderella," "Snow White," and "The Juniper Tree," may be more apt to accept that a woman's maturation culminates in the separation from, if not the rejection of, the mother figure. ${ }^{32}$ With few exceptions, the conventional fairy tale heroine's entrance in the adult world steers toward marriage (i.e. relocation to the husband's home) and subsequent 
domestication (childbirth, etc.). A return to her childhood home (i.e. to the mother/female mentor) is usually out of the question. To channel women's ambitions in this manner is not the goal of von Olfers' tale. The author instead allows her protagonists to pursue their dreams. Exploring their aspirations enables them to mature, stay independent, and find a suitable home. However, before they can satisfy their differing ambitions, they must learn to cooperate.

While the little princess' quest to 'cross over' initially leads to the break with her mother, the sprite seizes the opportunity to explore the home of her human counterpart. Rather than echoing the self-interest displayed by more traditional mermaid characters - the mermaids in Goethe's "The Fisher" and the Grimm tales "The Little Water Nixie" and "The Nixie in the Pond" simply seek to enchant, enslave, or even drown land dwellers — von Olfers instead depicts the exchanges between the sprite and her human acquaintance as mutual agreements, which grow reciprocally more considerate and result in an enduring friendship between the protagonists. While initially they trade places "fair and square," the young explorers eventually agree to live as sisters in the same house (222). ${ }^{33}$ The decision to compromise and settle on land in a matriarchal home is quintessential for their coming-of-age, as it carves out for them an alternative third space, a safe haven with possible access to both the water kingdom and the world of men ruled by the patriarch.

Von Olfers' illustration depicting the moment in which the sprite offers her treasures to the human child only underscores the kinship between the newly found sisters. The pudgy faces of both characters seem virtual carbon copies of 


\section{Sophie Journal}

each other. However, contrary to Annette Von Droste Hülshoff's The Jew's Birch (Die Judenbuche, 1842) or Robert L. Stevenson's The Strange Case of Dr Jekyll and Mr. Hyde (1886) that depict oppositional doubles competing with their host subjects in order to conquer them, the Doppelgänger character in von Olfers' tale accommodates the needs of her human counterpart and even protects her from harm. ${ }^{34}$ Indeed, the princess and her double switch places and, while crossing boundaries of their home environments, they undergo metamorphoses or learning processes. The human child begins to value her mother's care over all the riches the underwater kingdom may offer, while the sprite is moved to feel empathy for the growing homesickness of her human counterpart. Before both protagonists can live in the same home and enjoy the emotional attachment to the matriarch, they must learn to cooperate and, in the process, overcome their self-centeredness.

Much as it allows her heroines to undergo transformations, von Olfers' tale initiates a learning process in the reader. While many narratives that make up the fairy tale canon condition the reader to anticipate a tale of women characters pitted against each other, because they supposedly embody incompatible ambitions, "Little Princess" prescribes collaboration and compromise. The dilapidated mill von Olfers depicts in the beginning of her tale turns out to be a refuge with an open-door-policy for both a disenchanted nomad (the little princess) and a homeless stranger (the sprite). Not only does the author resurrect the matriarch as a dominant figure in the coming-of-age story of her protagonists, but she also undermines the idea of 'crossing over' expressed in the "The Little Mermaid." Her heroine regains access to the human world 
and returns to her mother's side, while Andersen's protagonist is barred from ever returning home, although she sacrifices everything ("But if you take away my voice, $[\ldots]$ what is left of me?): her home, her mobility, and her voice, and still falls short of obtaining the due reward (the hand of the prince). ${ }^{35}$

Contrary to the harsh reality of Andersen's tale, the adolescent girls in von Olfers' "Little Princess" are permitted to explore, err, and correct their mistakes. In the process of their crossing the threshold to and from the world of fish and humans, they dissolve the barriers between these spheres, that conventional fairytales depict as impermeable. The quintessential key to their ability to 'cross over' is collaboration. Von Olfers' characters grow more compassionate and cooperative in spite of their differences, and begin living together as sisters rather than competing for limited resources. In addition to highlighting their kinship, "Little Princess" celebrates the matriarchal, single-parent home as a pivotal element in the sisters' coming-of-age stories, one of which culminates in a mother-daughter reunification.

As the exploration of at least one heroine ironically culminates in a return to the origin (the maternal home), von Olfers' narrative connects to the broader Romantic themes of restoration and rebirth. Conversely, the sprite's coming-of-age story speaks of progress, of securing a new, better home. In the end, the protagonists establish a family that defies the principles of von Olfers' time. ${ }^{36}$ To be sure, their safe haven is located outside of patriarchal reach and thrives in its independence from it. It may be the narrative's oscillation between and validation of ostensibly competing, equally legitimate destinies that was to encourage nineteenth-century women readers to imagine living 


\section{Sophie Journal}

out their ambitions in an alternative third space.

This special realm carved out in von Olfers' narrative is perhaps an outgrowth of her collaboration with both established and aspiring women writers linked to the Kaffeterkereis, a forum that not only afforded young women the rare opportunity to articulate their cognitive maps of the world, but also allowed them to develop a form of Gegenöffentlichkeit (oppositional public sphere) that aimed to manipulate and re-shape the cultural underpinnings connecting all fairy tales. ${ }^{37}$ It therefore is not surprising that the author and her affiliates target the fairy tale, a literary form of "wish-fulfillment," and place it in the service of a dynamic process. ${ }^{38}$ Von Olfers' occupation with the aspirations fairy tales implant into young minds endorses the transformative power of the imagination as a unifying faculty, which reveals the previously hidden, gendered reality of the disadvantaged.

The specific focus on female exploration and collaboration in "Little Princess" brings to the forefront a gender-conscious re-vision of the classic fairy tale world. Von Olfers' "Little Princess" directs attention to the literary convention of abusing, domesticating, and silencing fairy tale heroines who refuse to conform to social conventions. With its aim to endorse awareness of these matters, "Little Princess" highlights ulterior venues for striving women which integrate collaboration and reaffirm the matriarch as a key figure in the formation of an alternative, voluntary form of family. There is little doubt that the alteration of fairy tale themes such as the female quest, the matriarchal home, and individual difference is deliberate. Von Olfers' fairy tale anticipates a growing effort to include the experiences of the underrepresented in a genre designated to educate the next generation of bourgeois wo/men. 
${ }^{1}$ Edward Said, Beginnings: Intention and Method, 83.

${ }^{2}$ Shawn Jarvis, "Von der Kinderstube zur Frauenstube: The Fairy Tale as a Product of the Literary Salon," Selecta; Karen Rowe, "To Spin a Yarn: The Female Voice in Folklore and Fairy Tale," Fairy Tales and Society: Illusion, Allusion, and Paradigm; Jeannine Blackwell "The Historical Context of German Women's Fairy Tales,” The Queen's Mirror.

${ }^{3}$ Zipes' term "contamination," referring to fairy tale evolution, may be a poor choice of words, as it indeed refers to a positive, enriching process rather than a corruptive one. According to Zipes, to contaminate an oral folk tale or literary tale is to enrich it by artfully introducing "extraordinary motifs, themes, words, expressions, proverbs, metaphors, and characters" into its corporate body, so that the narrative will be transformed and reflects a new essence ("The Contamination of the Fairy Tale, or The Changing Nature of the Grimm's Fairy Tales," Journal of the Fantastic in the Arts. 79).

${ }^{4}$ Zipes makes a more convincing case for fairy tales that contest gender prescriptions regurgitated in canonical tales, when he uses the term "progressive" narrative rather than "contamination" to describe them ("Spreading Tales, Opening Minds. Sample Sessions," in Speaking Out, 115).

${ }^{5}$ Together with the von Arnim and Bardua sisters, von Olfers founded the Kaffeterkreis (Ausstellungskatalog Freies Deutsches Hochstift).

${ }^{6}$ Ingeborg Drewitz, Berliner Salons: Gesellschaft und Literatur zwischen Aufklärung und Industriealter, 90.

${ }^{7}$ Marie von Olfers' tale "Little Princess" is included in The Queen's Mirror: Fairy Tales by German Women, 1780-1900, 217-223. The German original titled "Prinzeßchen" was published in 1862 in Drei Märchen. Zum Besten einer armen Waise, 26-40. I will reference quotations from the translation within the main text and give the original German version in footnotes.

At the peak of von Olfers' career, she mentored her niece, Sibylle, who eventually continued the family tradition of drafting and illustrating children's literature. In the early twentieth century, Sibylle became known 
at home and overseas for her book series When the Root Children Wake Up (Etwas von den Wurzelkindern).

${ }^{8}$ To date, there exists no scholarly interest in von Olfers' contribution to the genre of fairy tales.

9 "Auf dem Strohhaufen kugelte sich überseelig eine Herde Jungen, wohl an sieben Stück, alles Brüder" (26).

${ }^{10}$ Ruth Bottigheimer asserts that silencing women protagonists is one of the overriding tendencies of standard Grimm tales ("Silenced Women in the Grimms' Tales: The 'Fit' between Fairy Tales and Society in Their Historical Context"). Moreover, Marina Warner's study titled "Women against Women in the Old Wives' Tale" (in Cinema and the Realms of Enchantment) follows this notion even further, as the author demonstrates that the conventional fairy tale systematically erases the maternal force (i.e. the biological mother) from its plot to allow for a confrontation between the naïve heroines (in "Snow White," or "The Juniper Tree") and their wicked stepmothers. For more on the misogynic nature of Grimm tales, refer to Anne Leblans' "Kinder- und Hausmärchen: The Creation of Male Wombs as a Means of Protection against the Fear of Engulfment," in Subversive Sublimities: Undercurrents of the German Enlightenment and Jerilyn Fisher's and Ellen S. Silber's study titled "Fairy Tales, Feminist Theory, and the Lives of Women and Girls" (Analyzing the Different Voice).

${ }^{11}$ Grimm tales seeking to restore the patriarchal family structure are not limited to "Faithful Johannes," "The Three Little Gnomes in the Forest," "Cinderella," "The Juniper Tree," "The Six Swans," and "Snow White."

${ }^{12}$ Maria Tatar shows in "Daughters of Eve: Fairy-Tale Heroines and Their Seven Sins," that conventional tales depict vanity and pride to be the "deadly sins" of women protagonists. Indeed, conventional tales prescribe humiliation as a disciplinary tool that "sets straight" (i.e. domesticates) all too willful and ambitious heroines (Off with Their Heads. Fairytales and the Culture of Childhood, 98-99). Also speaking to the domestication of female characters in fairy tales is Ruth Bottigheimer's "Silenced Women in the Grimms' Tales," in Fairy Tales and Society: Illusion, Allusion and Paradigm. 
${ }^{13}$ The original text, titled "Prinzeßchen," states: "Die Jungen, ihre Brüder konnten nie Prinzen werden mit ihren Dickköpfen" (29). Rather than referring to a person's physical appearance (i.e. "fat heads"), von Olfers' use of the term Dickkopf directs attention to the stubborn or obstinate nature of the boys.

${ }^{14}$ The narrator describes the boys as "plumpe, grobe Bauerjungen" (29), who cannot become princes ("konnten nie Prinzen werden" 29).

${ }^{15}$ In her study titled "In den Kasten gesteckt: Goethes 'Neue Melusine,"” Christine Lubkoll effectively utilizes the letter exchange between Goethe and Schiller to substantiate her suspicion that Goethe plays up his disdain for marriage in the deliberate distortion and diminution of the original Melusine. In contrast to the formidable mermaid of the original legend, his version depicts the story of a woman who, after consummating the relationship with her philandering lover, transforms into a creature small enough to be confined to a box (60).

${ }^{16}$ Jacob and Wilhelm Grimm's "The Water Nixie" (267) and "The Nixie in the Pond" (527-531) were translated and published by Jack Zipes in The Complete Fairy Tales of the Brothers Grimm.

${ }^{17}$ Laura Sells, "Where Do the Mermaids Stand? Voice and Body in 'The Little Mermaid"” (178).

${ }^{18}$ In her study of Andersen's mermaid tale and its Disney adaptation, Laura Sells argues that "The Little Mermaid" emphasizes compliance over mobility, and depicts "the woman as man wants her to be" rather than the "woman for herself" (180).

19 "Könnt ihr mich nicht lieb haben, herzen, wie die Menschen es unter einander thun?" (33).

20 "'Weißt du nicht, was die will? Ich nicht, du auch nicht; nun dann wird es wohl Unsinn sein.' Damit schwammen sie gaukelnd vorüber“ (33).

${ }^{21}$ Helena Malzew's study Menschenmann und Wasserfrau dedicated a segment titled "Die Funktionen der Wasserfrau (mit Ausnahme von Liebesbeziehungen): Wasserfrau als Selbstporträt des Künstlers und Doppelgängerfigur" to the trope of the mermaid as double. She specifically 


\section{Sophie Journal}

stresses that in romantic prose, even the names of water creatures signal their existence as "Spiegelung" (i.e. mirror images) of humans (120).

22 "Dem Nixchen aber gefiel es auch nicht mehr da unten" (32).

23 “starr vor Entzücken" (31).

${ }^{24}$ The sea witch makes her proposition to the mermaid: "I will prepare a draught for you, [...] which you must drink [...] Your tail will then disappear, and shrink up into [...] legs, [...] but at every step you take it will feel as if you were treading upon sharp knives [...] You will never return [...] to your sisters, or to your father's palace again; [...] You have the sweetest voice of any who dwell here in the depths of the sea, [...] this voice you must give to me [...] Well, have you lost your courage? Put out your little tongue that I may cut it off as my payment" ("The Little Mermaid" transl. H.P Paull). The original text states: "Jeg skal lave dig en drik, [...] den skal du [...] drikke [...] Alle, som ser dig, vil sige, du er det dejligste mennesskebarn de har set [...] men hvert du gør, er som om du trådte på en skarp kniv [...] du kann aldrig stige ned igenem vandet til dine søstre og til din faders slot, [...] Du har den dejligste stemme af alle hernede påhavets bund [...] den stemme skal du give mig. Nå, har du tabt modet! Ræk frem din lille tunge, så skærer jeg den af, i betaling" ("Den lille Havefrue" Eventyre 98-99).

25 "jetzt planschte sie [...] wie eine kleine Wassernixe" (27).

26 "Das Wasser und das Kind, sie sahen aus wie verwünschte Prinzessinnen inmitten all' der Garstigkeit“" (27).

${ }^{27}$ Knaurs Lexikon der Symbole, 2002. "Wasser," 471-474 and "Wasserwesen," 475-476.

28 “'Prinzesschen,' rief sie [die Mutter], 'Du hättest ja ertrinken können! Die Wassernixe wär' ja gekommen und hätte dich in ihr Schloß geholt. Du Nichtsnutz, denk, von deiner Mutter fort in ihr Schloß.'“ (28).

29 “Alles so schön, so goldig! -Die große Kutsche, [...] die bunten Kleider, die Bedienten, welche noch stattlicher aussahen, als die Herren" (29). 
30 “ja selbst die Mutter konnte es [das Mädchen] häßlich finden [...], das graue Haar wie Zotteln, die Nase wie eine dicke, rote Kartoffel, und runzlig wie eine alte Hexe“ (29).

${ }^{31}$ Roberta Trites argues that the character of Ursula embodies the revolting, grotesque image of the smothering maternal mentor that must be extinguished. By Ariel's participation in the slaughter of Ursula, the mermaid relegates this vilified character and the feminine power she signifies to silence and absence, in order to keep the white male system functioning (148).

${ }^{32}$ All three tales depict an early separation from the biological mother, who is then replaced by a stepmother, an evil force that must be overcome before the heroine elopes.

33 "hatte es [das Nixchen] doch ehrlich mit dem Prinzeßchen darum getauscht" (38).

${ }^{34}$ There is ample evidence that many authors utilize the double to depict the tragic, demonic, or metaphysical disintegration of a character. For a more detailed discussion of the competitive, destructive Doppelgänger in German literature, turn to Chava Eva Schwarcz' "Der Doppelgänger in der Literatur" and Andrew J. Webber's study The Doppelgänger. For less common examples of the life-affirming uses of the double, turn to Christoph Forderer's "Der Doppelgänger als positives Phänomen." Among other examples of the positive double, Forderer points to Erich Kästner's Das doppelte Lottchen (1949) and argues that the author (much like von Olfers) uses the physical similarity between the two protagonists to reinforce the notion that they are of one and the same origin/home. Much like the twins in Kästner's novel, the little princess and the sprite eventually live as sisters in the same home.

35 “Men når du tager min stemme, [...] hvad beholder jeg da tilbage?” (99).

${ }^{36}$ In the nineteenth century unmarried (i.e. "redundant") women or "spinsters" were perceived as anomalies. Toward the middle of the 1800's, artists such as Richard Redgrave (1804-1888) and George Frederic Watts (1817-1904) chose to depict the "redundant woman," one of their favorite subject matters, as lonely, solitary outcasts, while William Rathbone Greg's essay "Why are Women Redundant?" (1864) animates readers to 


\section{Sophie Journal}

feel for the spinster, who against all convention must live independently and lonely, as she lacks a mate and children at her side (my emphasis, 436).

${ }^{37}$ The Kaffeter, at its core a Romantic salon, paved the way for women's participation in public debate, in that it provided a forum in which women could play out roles that seemed impossible in real life, while it also afforded its members an avenue to publish in the Kaffeterzeitung (Jarvis, "Trivial Pursuit?" 103). In his essay "The Limits of Patriarchy," Chris Weedon uses the term "Gegenöffentlichkeit" to refer to feminist literary ventures that articulate the interests of the marginalized (86).

${ }^{38}$ Jack Zipes, The Oxford Companion to Fairy Tales, 2000, xvii. 
REFERENCES:

Andersen, Hans Christian. "Den lille Havenfrue.” Eventyr. Vol.

1. Kopenhagen: Hans Reitzel, 1963. 87- 106.

---. "The Little Mermaid.” Fairy Tales. Trans. H.P. Paull. Ware,

England: Omega; Secaucus, N.J.: Chartwell, 1984.

Ausstellungskatalog: Freies Deutsches Hochstift. Frankfurt a.M. [n.d.]

Blackwell, Jeannine. "The Historical Context of German

Women's Fairy Tales.” The Queen's Mirror: Fairy Tales by

German Women, 1780-1900. Eds. Jeannine Blackwell and Shawn Jarvis. Lincoln: University of Nebraska Press, 2001. 1-9.

Bottigheimer, Ruth. "Silenced Women in the Grimms' Tales:

The 'Fit' Between Fairy Tales and Society in Their

Historical Context." Fairy Tales and Society: Illusion,

Allusion and Paradigm. Ed. Ruth Bottigheimer.

Philadelphia: University of Pennsylvania, 1986. 115-131.

Drewitz, Ingeborg. Berliner Salons: Gesellschaft und Literatur

zwischen Aufklärung und Industriealter. Berlin: Haude \& Spener, 1979.

Fisher, Jerilyn, and Ellen S. Silber. "Fairy Tales, Feminist Theory, and the Lives of Women and Girls." Analyzing the Different Voice. Feminist Psychological Theory and Literary Texts. Lanham, Boulder, New York, Oxford:

Rowman \& Littlefield, 1998. 67-95.

Forderer, Christoph. "Der Doppelgänger als positives

Phänomen.” Roczniki Humanistyczne 42:5 (1994): 25-40.

Greg, William Rathbone. "Why are Women Redundant?"

National Review 14 (1862): 
436.

Grimm, Jacob, and Wilhelm Grimm. "The Water Nixie." The

Complete Fairy Tales of the Brothers Grimm. $3^{\text {rd }}$ ed. Trans.

Jack Zipes. Bantam: New York, 2003. 267.

--. "The Nixie in the Pond." The Complete Fairy Tales of the

Brothers Grimm. $3^{\text {rd }}$ ed. Trans. Jack Zipes. Bantam: New York, 2003. 527-531.

Jarvis, Shawn. "Von der Kinderstube zur Frauenstube: The Fairy

Tale as a Product of the Literary Salon." Selecta 7 (1986):

98-103.

Knaurs Lexikon der Symbole. Ed. Hans Biedermann. $4^{\text {th }}$ ed.

Weltbild: Augsburg, 2002.

Leblans, Anne. "Kinder- und Hausmärchen: The Creation of Male Wombs as a Means of Protection against the Fear of

Engulfment." Subversive Sublimities: Undercurrents of the

German Enlightenment. Columbia SC: Camden, 1992. 8697.

Lubkoll, Christine. "In den Kasten gesteckt: Goethes 'Neue

Melusine." Sehnsucht und Sirene. Vierzehn Abhandlungen

zu Wasserphantasien. Ed. Irmgard Roeling. Paffenweiler:

Centaurus, 1991.

Olfers, Marie von. "Prinzeßchen." Drei Märchen. Berlin:

Rauck'sche Buchhandlung, 1862. 26-40.

---. "Little Princess.“ The Queen's Mirror: Fairy Tales by

German Women, 1780-1900. Eds. Jeannine Blackwell and

Shawn Jarvis. Trans. Shawn C. Jarvis. Lincoln: University of

Nebraska Press, 2001. 217-223.

Olfers, Sibylle von. When the Root Children Wake Up. San

Diego: Green Tiger Press, 1988.

Rowe, Karen. "To Spin a Yarn: The Female Voice in Folklore 
and Fairy Tale." Fairy Tales and Society: Illusion, Allusion,

and Paradigm. Ed. Ruth B. Bottigheimer. Philadelphia:

University of Pennsylvania, 1986. 53-74.

Said, Edward. Beginnings: Intention and Method. New York:

Basic Books, 1975.

Schwarcz, Chava Eva. "Der Doppelgänger in der Literatur.

Spiegelungen, Gegensatz, Ergänzung.“ Doppelgänger. Die

endlosen Spielarten eines Phänomens. Ed. Ingrid Fichtner.

Bern, Stuttgart, Wien: Paul Haupt, 1999. 1-14.

Sells, Laura. "'Where Do the Mermaids Stand?' Voice and Body

in 'The Little Mermaid." From Mouse to Mermaid. The

Politics of Film, Gender, and Culture. Eds. Elizabeth Bell,

Lydia Haas, and Laura Sells. Bloomington, Indianapolis:

Indiana University Press, 1995. 175-192.

Tatar, Maria. "Daughters of Eve: Fairy-Tale Heroines and Their

Seven Sins." Off With Their Heads. Fairytales and the

Culture of Childhood. Princeton: Princeton University

Press, 1992. 94-119.

Trites, Roberta. "Disney's Sub/Version of 'The Little

Mermaid." Journal of Popular Television and Film. 18 (1990/1991): 145-159.

Warner, Marina. "Women Against Women in the Old Wives'

Tale." Cinema and the Realms of Enchantment. London:

British Film Institute, 1993. 63-84.

Webber, Andrew J. The Doppelgänger. Double Visions in

German Literature. Oxford: Clarendon, 1996.

Weedon, Chris. "The Limits of Patriarchy." Textual Liberation:

European Feminist Writing in the Twentieth Century.

London: Routledge, 1991. 74-99

Zipes, Jack. "Spreading Tales, Opening Minds, Sample 


\section{Sophie Journal}

Sessions." Speaking Out. Storytelling and Creative Drama for Children. New York: Routledge, 2004. 111-162.

---. "The Contamination of the Fairy Tale, or The Changing Nature of the Grimm's Fairy Tales." Journal of the Fantastic in the Arts. 11:1 (2000): 77-93.

---. "Introduction." The Oxford Companion to Fairy Tales. Oxford: Oxford University Press, 2000. xv-xxxii. 